DE DE GRUYTER

OPEN

\title{
THE EFFECTS OF DIFFERENT STORAGE TEMPERATURES AND TIME ON THE SURVIVAL OF CPE (+) CLOSTRIDIUM PERFRINGENS TYPE A IN ÇİĞ KÖFTE (A TRADITIONAL TURKISH RAW MEAT PRODUCT)
}

\author{
Hüsnü Şahan Güran ${ }^{1 \bullet}$, Osman İrfan İlhak ${ }^{2}$ \\ ${ }^{1}$ Faculty of Veterinary Medicine, Department of Food Hygiene and Technology, \\ Dicle University 21280, Diyarbakir, Turkey \\ ${ }^{2}$ Faculty of Veterinary Medicine, Department of Food Hygiene and Technology, Firat University 23119, \\ Elazig, Turkey \\ •Corresponding author: sahanguran@yahoo.com or sguran@dicle.edu.tr
}

\begin{abstract}
This study was carried out to investigate the survival of cpe (+) Clostridium perfringens type A in çiğ köfte. For this purpose, çiğ köfte samples were artificially contaminated with the pathogen, and then the samples were stored at 4,24 and $30^{\circ} \mathrm{C}$ for $72 \mathrm{~h}$. The numbers of cpe $(+)$ Clostridium perfringens type A, total aerobic mesophilic bacteria (TAMB) and lactic acid bacteria (LAB) in the samples were analysed at $6,12,24,48$ and $72 \mathrm{~h}$ of storage. The number of the pathogen in the samples stored at $30^{\circ} \mathrm{C}$ significantly decreased during the storage and dropped below detection level $(10 \mathrm{cfu} / \mathrm{g})$ after $48 \mathrm{~h}$ while the reduction number of the pathogen in the samples stored at $4^{\circ} \mathrm{C}$ was $1.60 \mathrm{log} \mathrm{cfu} / \mathrm{g}$ at the end of the $72 \mathrm{~h}$. The numbers of the TAMB and LAB in the samples stored at $24^{\circ} \mathrm{C}$ and $30^{\circ} \mathrm{C}$ rapidly increased compared to the samples stored at $4^{\circ} \mathrm{C}$ during the storage period $(\mathbf{P}<\mathbf{0 . 0 5})$. This study demonstrates that this pathogen can survive in çiğ köfte stored at refrigeration temperature for more than 3 days, but cannot survive at $30^{\circ} \mathrm{C}$ for 3 days.
\end{abstract}

Key words: cpe $(+) C$. perfringens type $\mathrm{A}$, time, temperature, çiğ köfte, survival

A ready-to-eat (RTE) food is any food which does not undergo any treatment to ensure its safety before consumption. Therefore, the RTE foods may cause foodborne disease if they are not prepared properly, or if they are contaminated with foodborne pathogens before/after production (Gibbons et al., 2006; Angelidis et al., 2006). Çiğ köfte (raw meatball) contains raw ground beef and is a popular traditional homemade RTE food in Turkey, especially Eastern and Southeastern regions of Turkey, and in some Middle East countries (Dogan et al., 2014). Çiğ köfte is simply prepared by mixing bulgur wheat which is a cracked wheat, lean ground beef, salt, chopped onion, garlic, tomato and red pepper pastes, parsley and spices (Sagun et al., 2003; Dikici et al., 2013). Ratio of bulgur and ground beef is about 2:1. The ingredients 
are added to bulgur and thoroughly kneaded by hand. There is no heating step in its preparation. After kneading, the resulting product is formed into small ellipsoidal shape and served. In general, çiğ köfte is kept at room temperature (ca. $22-25^{\circ} \mathrm{C}$ ) and consumed during the day. However, in recent years, commercially produced çiğ köfte can be kept in refrigerator temperatures for 24 hours or more (Durmaz et al., 2007; Kilic, 2009). On the other hand, homemade çiğ köfte may be kept by the household more than a day.

There are various studies conducted on microbiological quality of çiğ köfte in different cities in Turkey (Elmali and Yaman, 2005; Cetin et al., 2008; Şireli et al., 2008; Ardiç and Durmaz, 2008; Bingöl et al., 2013; Bingöl et al., 2014). Results of these studies showed that çiğ köfte may harbor pathogenic bacteria and fecal indicator bacteria including Escherichia coli, coliforms, Salmonella spp., Listeria monocytogenes, Staphylococcus aureus, Yersinia enterocolitica and Bacillus cereus. A study on çiğ köfte inoculated with Salmonella Enteritidis (about $3.0 \log _{10} \mathrm{cfu} / \mathrm{g}$ ) showed that the number of Salmonella Enteritidis in çiğ köfte did not significantly change during $24 \mathrm{~h}$ storage (Uzunlu and Yildirim, 2003). Another study conducted on the survival and growth of two L. monocytogenes serotypes $1 / 2 \mathrm{~b}$ and $4 \mathrm{~b}\left(4.0 \log _{10}\right.$ $\mathrm{cfu} / \mathrm{g}$ ) in çiğ köfte stored at 4 and $21^{\circ} \mathrm{C}$ reported that L. monocytogenes is capable of survival and growth in çiğ köfte at both storage temperatures (Durmaz et al., 2007). Although each ingredient in çiğ köfte may contribute to the microbial health risks, the ground beef is the major contributor because it is well known that a variety of foodborne pathogenic bacteria can be found in ground beef (Sofos, 2008). In Turkey, there is no detailed database about the hospital records arising from foodborne pathogens.

It has been reported that only a small fraction of all $C$. perfringens, mainly belonging to type $\mathrm{A}$, are capable of producing an intestinally active enterotoxin (cpe $=C$. perfringens enterotoxin gene) (Brynestad and Granum, 2002; Durre, 2005). cpe $(+)$ C. perfringens type $\mathrm{A}$ is one of the most common agents causing foodborne poisonings each year in many countries (Garcia and Heredia, 2011). C. perfringens is able to grow rapidly under the optimum conditions, and the ingestion of $10^{6}-10^{7}$ living $C$. perfringens cells per gram of food can cause foodborne intoxication (Batt and Patel, 2000). Since the bacterium has some amino acid requirements for growth, meat and meat-containing foods provide good environments for growth. In a study conducted by Guran et al. (2014) in Turkey, it has been reported that $96 \%$ of ground beef samples collected from retail markets were found to be contaminated with C. perfringens, and the researchers noted that $77.4 \%$ of positive isolates were C. perfringens type A, $2.2 \%$ of isolates were cpe $(+)$ C. perfringens type A.

Although there are many articles reporting poor microbiological quality of çiğ köfte (Vural and Yeşilmen, 2003; Sagun et al., 2003; Küplülü et al., 2003; Daglioglu et al., 2005; Elmali and Yaman, 2005; Sancak and İşleyici, 2006; Cetin et al., 2008), there is no published data about the survival of cpe $(+)$ C. perfringens type A in çiğ köfte. We believe that çiğ köfte is common and popular enough to deserve a scientific evaluation for surviving of $C$. perfringens. Therefore, the present study was conducted to investigate the survival of cpe $(+) C$. perfringens type A in çiğ köfte stored at 4,24 and $30^{\circ} \mathrm{C}$ for 72 hours. 


\section{Material and methods}

\section{Preparation of inoculum}

NCTC 8239 strain (Hobbs serotype 3) of cpe $(+)$ C. perfringens type A was used. Inoculum was prepared using a method reported by Guran and Oksuztepe (2014). Briefly, the strain was cultured in $10 \mathrm{ml}$ of Fluid Thioglycollate Medium (FTM, Merck, Darmstadt, Germany) and incubated at $37^{\circ} \mathrm{C}$ for $18 \mathrm{~h}$ under anaerobic conditions. Then, $1 \mathrm{ml}$ culture was transferred to another tube containing $9 \mathrm{ml}$ FTM and incubated at $37^{\circ} \mathrm{C}$ for $6 \mathrm{~h}$ under anaerobic conditions. After that, $1 \mathrm{ml}$ of the $6 \mathrm{~h}$ culture was transferred to $9 \mathrm{ml}$ of the FTM and incubated for $18 \mathrm{~h}$. At the end of the incubation period, the culture was centrifuged at $4200 \times \mathrm{g}$ for $10 \mathrm{~min}$ at room temperature and the pellet was washed with $0.1 \%$ sterile peptone water before recentrifuging to remove organic residues. The pellet was then re-suspended in $10 \mathrm{ml}$ $0.1 \%$ sterile peptone water.

\section{Inoculation of ciğ köfte}

The experiment was repeated three times with intervals of a week. For each trial, $750 \mathrm{~g}$ of çiğ köfte was used. Çiğ köfte was prepared freshly by a local restaurant which was randomly selected. Since there is no standard related to production of çiğ köfte, which may differ from recipe to recipe, the restaurant was asked to prepare the çiğ köfte in the way it is prepared for their customers. In the present study, all ingredients used by the restaurant were presented in Table 1 as $\mathrm{g} / \mathrm{kg}$ çiğ köfte.

Table 1. Approximate amounts of ingredients used in making the çiğ köfte $(\mathrm{g} / \mathrm{kg})$

\begin{tabular}{l|c|l|c}
\hline \multicolumn{1}{c|}{ Ingredients } & Amount & \multicolumn{1}{c}{ Ingredients } & Amount \\
\hline Bulgur (cracked wheat) & 400 & Salt & 5 \\
Lean ground beef & 200 & Garlic & 5 \\
Tomato paste & 200 & Pimento & 4 \\
Chopped onion & 70 & Cumin & 3 \\
Parsley & 30 & Black pepper powder & 1.5 \\
Red pepper paste & 50 & Cinnamon & 1.5 \\
Water & $30^{*}$ & & \\
\hline
\end{tabular}

$* \mathrm{ml} / \mathrm{kg}$.

After the çiğ köfte was brought to our laboratory in $20 \mathrm{~min}$, it was artificially contaminated with cpe $(+)$ C. perfringens type A and mixed by hand using sterile gloves. The çiğ köfte batch was then divided into three groups, placed in foam plates and wrapped with plastic wrap. The groups were stored at 4,24 and $30^{\circ} \mathrm{C}$ and analysed at 0 (immediately after inoculation), 6, 12, 24, 48 and $72 \mathrm{~h}$ for microbiological condition and $\mathrm{pH}$ measurements.

\section{Microbiological analyses of the samples}

At each sampling time, a çiğ köfte sample of $25 \mathrm{~g}$ was taken from each group,

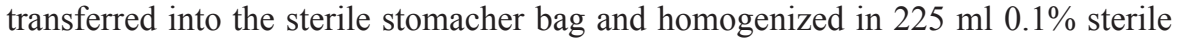
peptone water using a bagmixer Stomacher 400 (Interscience, St. Norm, France). Homogenized samples $\left(10^{-1}\right)$ were serially diluted in $0.1 \%$ sterile peptone water 
(Lab M, England) and pour plated on Tryptose Sulfite Cycloserine (TSC, LAB M, England) agar with D-cycloserine (TSC supplement, Lab M, England) for enumeration of $C$. perfringens. Characteristic colonies were counted after the plates were incubated at $37^{\circ} \mathrm{C} \pm 1$ for $24 \pm 3 \mathrm{~h}$ in an anaerobic jar (Guran and Oksuztepe, 2014). Five randomly selected colonies from TSC agar plates for each storage group were analysed for confirmation of the cpe $(+)$ Clostridium perfringens type A. Confirmation of the pathogen was carried out by simplex PCR using cpa and cpe specific primers, which were cpal (5'-GCT AAT GTT ACT GCC GTT GA-3') and cpa2 (5'-CCT CTG ATA CAT CGT GTAAG-3'), cpel (5'-GGA GAT GGT TGG ATA TTA GG-3') and cpe 2 (5'- GGA CCA GCA GTT GTA GATA-3') (Meer and Songer, 1997).

When the number of the pathogen dropped below the detection limit $(10 \mathrm{cfu} / \mathrm{g})$, the pre-enrichment procedure described by Schalch et al. (1996) was performed for the samples. In addition, those samples were analysed for the presence of the spore forming C. perfringens using the method described by Juneja et al. (2008). Briefly, a çiğ köfte sample of $25 \mathrm{~g}$ was placed into the sterile stomacher bag and homogenized in $225 \mathrm{ml} 0.1 \%$ sterile peptone water. Homogenized sample was transferred into the sterile erlenmeyer flask and then exposed to heat treatment of $20 \mathrm{~min}$ at $75^{\circ} \mathrm{C}$. One milliliter of the heat-shocked sample was placed on petri-plates containing a thin layer of TSC agar and subsequently mixed with $15 \mathrm{ml}$ of tempered TSC agar. After solidification of the TSC medium, the petri dishes were overlaid with an additional $5 \mathrm{ml}$ of TSC agar and incubated at $37^{\circ} \mathrm{C}$ in an anaerobic jar for $24 \mathrm{~h}$. Total aerobic mesophilic bacteria (TAMB) was enumerated by pour plate method using Plate Count Agar (PCA, LAB M, England) incubated at $35^{\circ} \mathrm{C}$ for $48 \mathrm{~h}$ (FDA/BAM 2001). Lactic acid bacteria (LAB) were enumerated on de Man Rogosa Sharpe Agar (MRS, LAB M, England) incubated at $30^{\circ} \mathrm{C}$ for $48 \mathrm{~h}$. All microbiological tests were performed in duplicate, and the results were expressed as the logarithm of the colony forming units per gram $\left(\log _{10} \mathrm{cfu} / \mathrm{g}\right)$.

\section{pH measurements}

At each sampling time, a çiğ köfte sample of $10 \mathrm{~g}$ was taken from each group, transferred into the stomacher bag containing $90 \mathrm{ml}$ distilled water and homogenized for 2 min. After homogenization, $\mathrm{pH}$ of the samples was measured using a digital $\mathrm{pH}$ meter (Selecta pH 2001, Spain).

\section{Statistical analysis}

Statistical analyses of the data obtained from three independent replicates were conducted using Statistical Analyses System (SAS Institute, Cary, NC, v. 8.0, 1999). The numbers of bacteria were converted to logarithmic values before calculating means and performing statistical analyses. When the numbers of $C$. perfringens decreased below the detection limit, a value of $0.8 \log _{10}$ cfu/g was recorded to perform statistical analysis. The data were subjected to three way Analysis of Variance (ANOVA) appropriate to replicates $\times$ storage groups $\times$ sampling time to determine fixed effects and interactions between variables. The means were separated using Fisher's least significant differences (LSD) according to general linear model (GLM) procedures. The level of significance (alpha) was set equal to 0.05 . 


\section{Results}

Effects of storage temperature of $4^{\circ} \mathrm{C}$ on the number of cpe $(+)$ C. perfringens type A, TAMB and LAB are shown in Figure 1. After inoculation, initial number of cpe (+) C. perfringens type A, TAMB and LAB were 7.58, 5.48 and $3.92 \log _{10} \mathrm{cfu} / \mathrm{g}$, respectively. In the sample stored at $4^{\circ} \mathrm{C}$, only a $1.14 \log _{10}$ cfu/g reduction was observed in the number of the pathogen in $24 \mathrm{~h}$. The reduction level in the number of the pathogen was $1.6 \log _{10} \mathrm{cfu} / \mathrm{g}$ at the end of the storage of $72 \mathrm{~h}$. In this group, the numbers of TAMB and LAB continuously increased during the storage and reached 7.78 and $5.88 \log _{10} \mathrm{cfu} / \mathrm{g}$ at the end of the storage, respectively (Figure 1).

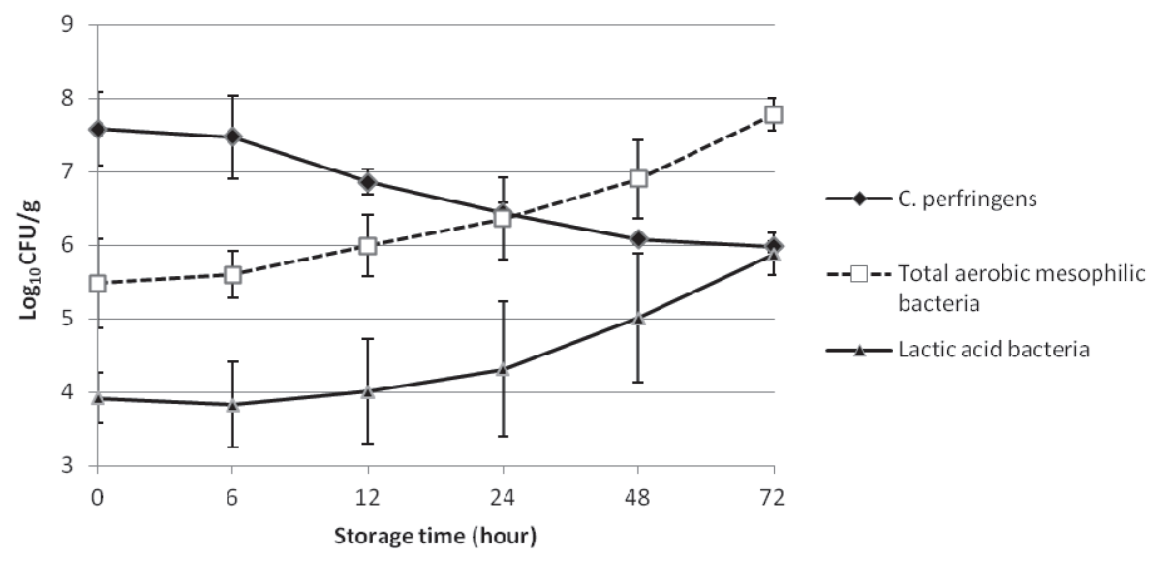

Figure 1. Changes in the numbers of cpe $(+)$ Clostridium perfringens Type A, TAMB and LAB in the çiğ köfte stored at $4^{\circ} \mathrm{C}$ for $72 \mathrm{~h}$

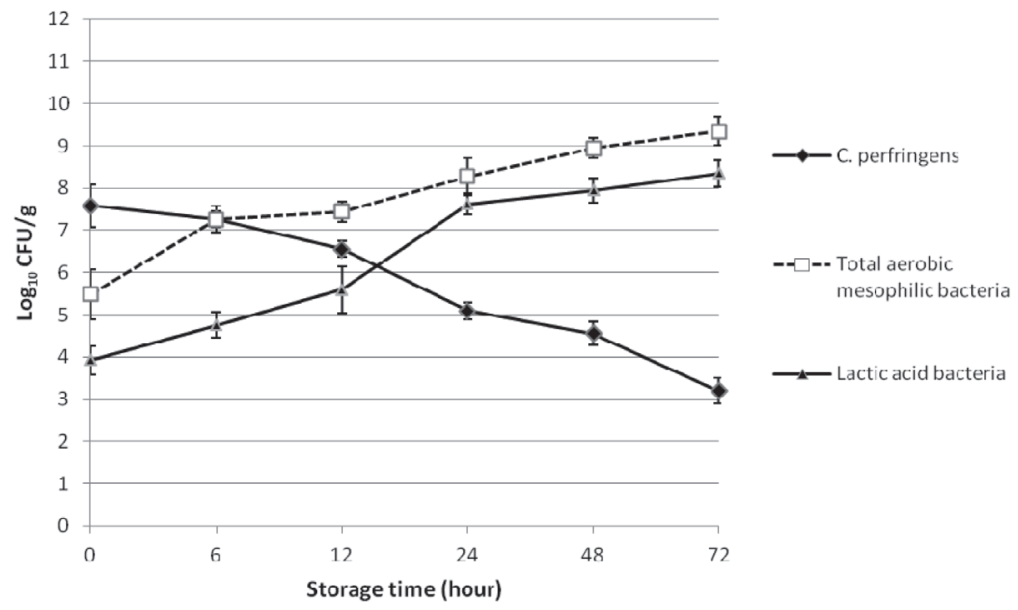

Figure 2. Changes in the numbers of cpe $(+)$ Clostridium perfringens Type A, TAMB and LAB in the çiğ köfte stored at $24^{\circ} \mathrm{C}$ for $72 \mathrm{~h}$ 
The reduction number of cpe $(+) C$. perfringens type A in çiğ köfte stored at $24^{\circ} \mathrm{C}$ was $2.49 \log _{10}$ at $24 \mathrm{~h}$ and $4.38 \log _{10} \mathrm{cfu} / \mathrm{g}$ at $72 \mathrm{~h}$ (Figure 2). The numbers of TAMB and LAB in this sample rapidly increased and reached 8.27 and $7.62 \log _{10} \mathrm{cfu} / \mathrm{g}$ in $24 \mathrm{~h}$, respectively, and their numbers were 9.35 and $8.35 \log _{10} \mathrm{cfu} / \mathrm{g}$ at the end of the storage, respectively (Figure 2). Statistical analyses showed that there were significant differences between the samples stored at $4^{\circ} \mathrm{C}$ and $24^{\circ} \mathrm{C}$ after storage of $12 \mathrm{~h}$ in point of the pathogen reduction level $(\mathrm{P}<0.05)$.

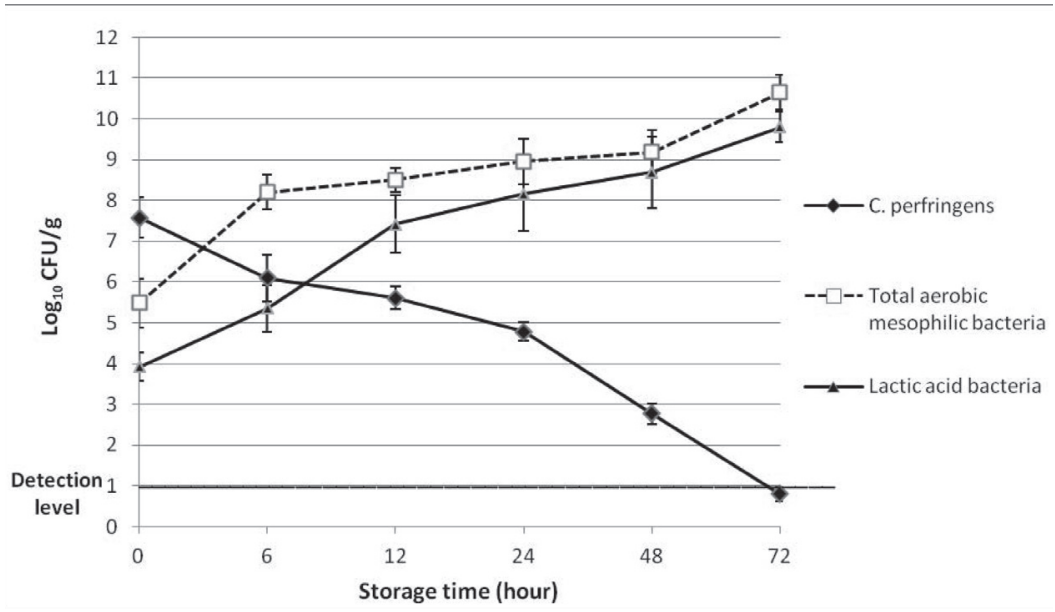

Figure 3. Changes in the numbers of cpe $(+)$ Clostridium perfringens Type A, TAMB and LAB in the çiğ köfte stored at $30^{\circ} \mathrm{C}$ for $72 \mathrm{~h}$

The number of cpe $(+)$ C. perfringens type A in çiğ köfte stored at $30^{\circ} \mathrm{C}$ rapidly decreased and dropped below the detection limit (10 cfu/g) within $72 \mathrm{~h}$ (Figure 3). The reduction number of the pathogen was $2.8 \log _{10}$ at $24 \mathrm{~h}$ and $4.81 \log _{10} \mathrm{cfu} / \mathrm{g}$ at $48 \mathrm{~h}$. Significant differences were observed between the samples stored at $4^{\circ} \mathrm{C}$ and $30^{\circ} \mathrm{C}$ after storage of $6 \mathrm{~h}$ in point of the pathogen reduction level $(\mathrm{P}<0.05)$. In this group, the numbers of TAMB and LAB rapidly increased with the effect of the increased temperature and reached 10.65 and $9.80 \log _{10} \mathrm{cfu} / \mathrm{g}$ at the end of the storage, respectively (Figure 3).

The initial pH level of the çiğ köfte was 5.57 (Table 2). During the storage, the $\mathrm{pH}$ level of the samples continuously decreased, regardless of the storage temperatures. After the storage of $24 \mathrm{~h}$, a significant difference was observed between the samples stored at $4^{\circ} \mathrm{C}$ and the samples stored at 24 or $30^{\circ} \mathrm{C}$. 
Table 2. Changes in the $\mathrm{pH}$ level of çiğ köfte stored at 4,24 , and $30^{\circ} \mathrm{C}$ during storage period of $72 \mathrm{~h}$

\begin{tabular}{|c|c|c|c|c|c|c|}
\hline \multirow{2}{*}{ Storage temperature $\left({ }^{\circ} \mathrm{C}\right)$} & \multicolumn{6}{|c|}{ Storage time $(\mathrm{h})$} \\
\hline & 0 & 6 & 12 & 24 & 48 & 72 \\
\hline 4 & 5.57 & $5.56 \mathrm{Ax}$ & $5.66 \mathrm{Ax}$ & $5.39 \mathrm{Ax}$ & $5.09 \mathrm{Ax}$ & $5.01 \mathrm{Ax}$ \\
\hline 24 & & $5.54 \mathrm{Ax}$ & $5.56 \mathrm{Ax}$ & 4.60 By & 4.24 By & 4.22 By \\
\hline 30 & & $5.52 \mathrm{Ax}$ & $5.48 \mathrm{Ax}$ & 4.44 By & 4.15 By & 4.02 By \\
\hline
\end{tabular}

A, B - numbers in the same column with the different superscript are significantly different $(\mathrm{P}<0.05)$. $\mathrm{x}, \mathrm{y}-$ numbers in the same row with the different superscript are significantly different $(\mathrm{P}<0.05)$.

\section{Discussion}

It is well known from the literature that the growth temperature range for $C$. perfringens is between 20 and $50^{\circ} \mathrm{C}$, and it does not grow at $4^{\circ} \mathrm{C}$ (Batt and Patel, 2000; Jay et al., 2005). This pathogen is also sensitive to low temperature storage, and vegetative cells inoculated into meat are slowly inactivated when the meat is held at $1.5-10^{\circ} \mathrm{C}$ (Batt and Patel, 2000). In our study too, C. perfringens did not multiply in çiğ köfte stored at $4^{\circ} \mathrm{C}$, and its number slowly decreased (Figure 2). However, although the temperatures of the samples stored at $24^{\circ} \mathrm{C}$ and $30^{\circ} \mathrm{C}$ are suitable for the growth of the $C$. perfringens, the reduction level of the pathogen is more rapid and higher than that in the sample stored at $4^{\circ} \mathrm{C}$ (Figure 2 and 3 ). At the same time, results of the study show that the number of cpe $(+) C$. perfringens type A rapidly decreased and dropped below the detection limit within $72 \mathrm{~h}$ while the numbers of TAMB and $\mathrm{LAB}$ rapidly increased in the sample stored at $30^{\circ} \mathrm{C}$. This finding may be explained by competitive exclusion. Many researchers have reported that lactic acid bacteria play an essential role in foods to prevent the growth of pathogenic microorganisms through acidification and competition for essential nutrients (Sancak and İşleyici, 2006; Durmaz et al., 2007; Ardıç and Durmaz, 2008).

It has been also reported that the level of $\mathrm{pH}$ has a significant effect on the growth of C. perfringens, and C. perfringens cannot grow below pH 5 (Jay et al., 2005; Riemann and Cliver, 2006). In our study, the $\mathrm{pH}$ level of the sample stored at $4^{\circ} \mathrm{C}$ did not drop below 5 during the storage whilst the $\mathrm{pH}$ level of the samples stored at $24^{\circ} \mathrm{C}$ and $30^{\circ} \mathrm{C}$ decreased to 4.60 and 4.44 in $24 \mathrm{~h}$, respectively (Table 2). These decreases can be explained by the activity of lactic acid bacteria and other acid-producing bacteria in the product. At the end of the storage $(72 \mathrm{~h})$, the $\mathrm{pH}$ level of the sample stored at $30^{\circ} \mathrm{C}$ decreased to 4.02 , and cpe $(+)$ C. perfringens type A was not detected in this sample. Since spores play an essential role in the pathogenesis of $C$. perfringens, this sample was analysed for the presence of the spore-forming cpe $(+) C$. perfringens type A. Spore-forming C. perfringens was not detected in the sample. It may be due to the low $\mathrm{pH}$ level. The $\mathrm{pH}$ level should be between 6.0 and 8.0 for the sporulation of $C$. perfringens (Doyle, 1989). It appears that the cumulative stresses of low $\mathrm{pH}$ and competition with large numbers of saprophytic organisms may have caused the death of cpe $(+) C$. perfringens type A. On the other hand, although several ingredients (salt, onion, garlic and pepper) used in the production of çiğ köfte have an 
antimicrobial effect, when considering the different bacterial reductions between the different storage temperatures, it can be said that the antimicrobial effects of these ingredients remain in the backstage.

As mentioned before, çiğ köfte is a ready-to-eat meat product which does not undergo the thermal treatment to inactivate pathogenic microorganisms. It is always possible that çiğ köfte can be highly or slightly contaminated with cpe $(+)$ C. perfringens type A because this pathogen is described as ubiquitous pathogenic bacterium in our environment. The findings of the present study show that keeping çiğ köfte at $24^{\circ} \mathrm{C}$ or $30^{\circ} \mathrm{C}$ may be more suitable than keeping it at $4^{\circ} \mathrm{C}$ for the rapid inactivation of cpe (+) C. perfringens type A. However, we cannot speculate that çiğ köfte stored at $24^{\circ} \mathrm{C}$ or $30^{\circ} \mathrm{C}$ is safer than those stored at refrigeration temperature, from a public health standpoint. In addition, in the present study we used only one strain of cpe $(+)$ $C$. perfringens type A and the çiğ köfte samples were obtained from only one restaurant. Therefore, the inter-strain variability of the pathogen was not investigated, and it should not be ignored that the composition of çiğ köfte may change more or less. Nevertheless, the present study exhibits the behaviour of the cpe $(+)$ C. perfringens type A in çiğ köfte stored at different storage temperatures.

\section{References}

Ange 1 i d is A.S., Chron is E.N., P a p a g e org i o u D.K., K a z a k is I.I., A rs en o glou K.C., Stathopoulos G.A. (2006). Non-lactic acid, contaminating microbial flora in ready-to-eat foods: A potential food-quality index. Food Microbiol., 23: 95-100.

A rd i ç M., D u r m a z H. (2008). Determination of changes occurred in the microflora of cig kofte (raw meat balls) at different storage temperatures. Int. J. Food Sci. Technol., 43: 805-809.

B a t t C.A., P a te 1 P.D. (2000). Editors. Encyclopedia of Food Microbiology. California, USA, Academic Press, 2372 pp.

B ing öl E.B., Çet in Ö., Üz ü m H.Ç., H a m p i k y a n H. (2013). Effects of sodium lactate on the presence of Staphylococcus aureus and enterotoxins in çiğ köfte (raw meatball). Turk. J. Vet. Anim. Sci., 37: 719-726.

B ingöl E.B., Çolak H., Çetin Ö., Ha mpikyan H. (2014). Effects of sodium lactate on the shelf life and sensory characteristics of çiğ köfte - a Turkish traditional raw meatball. J. Food Process. Pres., 38: 1024-1036.

Brynestad S., Granum P.E. (2002). Clostridium perfringens and foodborne infections. Int. J. Food Microbiol., 74: 195-202.

C e t i n O., B in g o 1 E.B., A k k a y a H. (2008). The microbiological, serological and parasitological quality of cig kofte (raw meatball) and its lettuce marketed in Istanbul. Pol. J. Environ. Stud., 17: 701-706.

Daglioglu F., Ilas la n N., Y il maz I. (2005). The microbiological quality of cig kofte sold in Istanbul, Turkey. Fleischwirtschaft International, 1: 10-12.

D i k i c i A., İ $1 \mathrm{~h}$ a k O.İ., Ç a $11 \mathrm{c} 1 \mathrm{oğ} l \mathrm{u}$ M. (2013). Effects of essential oils compounds on survival of Listeria monocytogenes and Escherichia coli O157:H7 in çiğ köfte. Turk. J. Vet. Anim. Sci., 37: 177-182.

D o gan M., C a n kurt H., Toker O.S., Yet i m H., S a g d i c O. (2014). Effect of yoghurt or yoghurt serum on microbial quality of cig kofte. J. Food Sci. Technol., 51: 1406-1410.

D o y le M.P. (1989). Foodborne Bacterial Pathogens. New York, USA, Marcel Dekker, pp. 796.

D u r m a z H., S a g u n E., S a n c a k H., S a g d i c O. (2007). The fate of two Listeria monocytogenes serotypes in "cig kofte" at different storage temperatures. Meat Sci., 76: 123-127.

D u r r e P. (2005). Editor. In Handbook on Clostridia. Taylor and Francis, Florida, USA, CRC Press, $920 \mathrm{pp}$. 
E $1 \mathrm{~m}$ a li M., Ya ma n H. (2005). Microbiological quality of raw meat balls: Produced and sold in the eastern of Turkey. Pakistan J. Nut., 4: 197-201.

Food and Drug Administration Bacteriological analytical manual (FDA/BAM). (2001): Aerobic Plate Count, Chapter 3. Available at http:/www.fda.gov/food/foodscienceresearch/laboratorymethods/ ucm063346.htm Site accessed on September 9, 2014.

Garcia S., Heredia N. (2011). Clostridium perfringens: A Dynamic Foodborne Pathogen. Food Bioprocess Tech., 4: 624-630

Gibbons I., Adesiyun A., Seepersadsingh N., Rahaman S. (2006). Investigation for possible source(s) of contamination of ready-to-eat meat products with Listeria spp. and other pathogens in a meat processing plant in Trinidad. Food Microbiol., 23: 359-366.

G u r a n H.S., O k s u z t e p e G. (2014). The influence of different freezing and frozen storage temperatures on Clostridium perfringens type A in raw chicken wings. J. Food Agric. Environ., 12: 8-11.

Guran H.S., Vural A., Erka n M.E. (2014). The prevalence and molecular typing of Clostridium perfringens in ground beef and sheep meats. J. Verbrauch. Lebensm., 9: 121-128.

J a y J.M., L o e s s ner M.J., G olden D.A. (2005). Editors. Modern Food Microbiology. Springer Science, New York, 7th ed., 790 pp.

Jun eja V.K., Marks H., Thippareddi H. (2008). Predictive model for growth of Clostridium perfringens during cooling of cooked uncured beef. Food Microbiol., 25: 42-55.

K i 1 i c B. (2009). Current trends in traditional Turkish meat products and cuisine. LWT-Food Sci. Technol., 42: 1581-1589.

K ü plülü Ö., S a ri m e h m e t o ğlu B., Oral N. (2003). The microbiological quality of çiğ köfte sold in Ankara (in Turkish). Gida, 28: 379-384.

M e e r R.R., S o n g e r J.G. (1997). Multiplex polymerase chain reaction assay for genotyping $C$. perfringens. Am. J. Vet. Res., 58: 702-705.

R i e m ann H.P., C liver D.O. (2006). Editors. Food borne Infections and Intoxications. London, Amsterdam, Academic Press (Elsevier), 3rd ed., 903 pp.

S a gun E., A lis arli M., D u rmaz H. (2003). The effect of different storage temperatures on the growth and enterotoxin producing characteristics of Staphylococcus aureus in cig kofte (in Turkish). Turk. J. Vet. Anim. Sci., 27: 839-845.

S a n c a k Y.C., İ ş l e y i c i Ö. (2006). A study on the Microbiological Quality of Cig Kofte (in Turkish). The Journal of the Faculty of Veterinary Medicine University of Yuzuncu Y11, 17: 81-86.

Schalch B., Eis gruber H., Geppert P., Stolle A. (1996). Vergleich von vier Routineverfahren zur Bestaetigung von Clostridium perfringens aus Lebensmitteln. Arch. Lebensmittelhyg., 47: 27-30.

Ş ir e li U.T., G ön c ü o ğ lu M., P e h li va n l ar S. (2008). Growth of Listeria monocytogenes in cig kofte (raw meat ball). Veterinary Journal of Ankara University, 55: 83-87.

S o f o s J.N. (2008). Challenges to meat safety in the 21st century. Meat Sci., 78: 3-13.

Uzunlu S., Yildirim I. (2003). Microbiological quality of raw meat ball and investigation of its microbial variation at the different storage time and temperature (in Turkish). G1da, 28: 553-558.

Vu r a 1 A., Y e ş i $1 \mathrm{~m}$ e n S. (2003). A study on microbiological quality of raw meatball sold in Diyarbakır (in Turkish). Türk Mikrobiyoloji Cemiyeti Dergisi, 33: 350-355.

Received: 6 VIII 2014

Accepted: 3 X 2014 